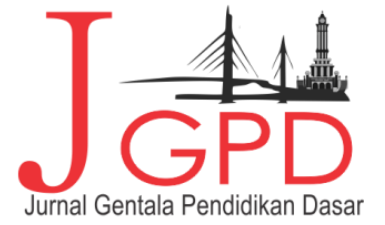

Artikel Penelitian

\title{
Penerapan Model Pembelajaran Kooperatif Tipe Roundtable Berbantuan Media Gambar Seri Dalam Meningkatkan Kemampuan Menulis Cerita Pendek Pada Siswa Sekolah Dasar
}

\section{Hamelia Agustina}

Prodi Magister Pendidikan Dasar, Pascasarjana Universitas Jambi, Jambi, Indonesia

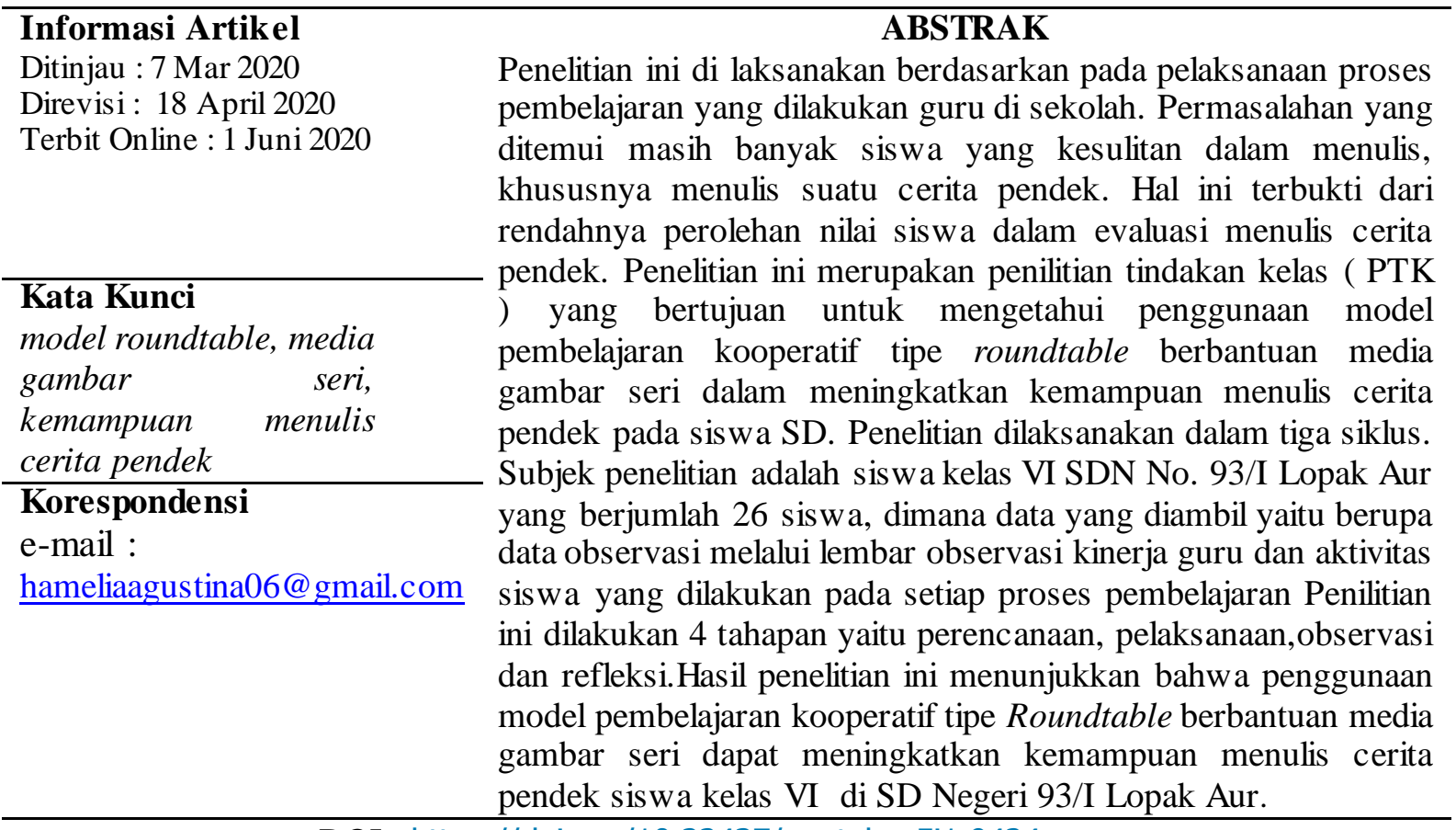

DOI : https://doi.orq/10.22437/gentala.v5i1.9424

\section{PENDAHULUAN}

Bahasa Indonesia merupakan salah satu pembelajaran yang sangat penting, karena dalam Bahasa Indonesia terdapat empat aspek keterampilan berbahasa yang harus dikuasai dan berperan penting yaitu menulis, membaca, menyimak, dan berbicara. Keterampilan menulis sebagai salah satu keterampilan dari empat keterampilan berbahasa yang mempunyai peranan yang sangat penting dalam kehidupan.

Salah satu kompetensi yang diajarkan di kelas VI adalah menulis cerita fiksi dalam bentuk cerita pendek. Mastini, Suwandi, dan Sumarwati (2016) menyatakan cerita pendek adalah karya sastra berbentuk prosa yang isi ceritanya mengisahkan permasalahan kehidupan suatu tokoh yang diceritakan secara ringkas dan berfokus pada suatu tokoh, serta dimediakan secara lisan ataupun tulisan. 


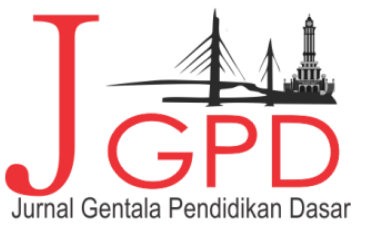

JURNAL GENTALA PENDIDKAN DASAR Vol.5 No. I Juni 2020, Halaman 78-90 P-ISSN : 2614-7092, E-ISSN : 2621-96II Terbit Online Pada Laman Web : hittp://online-journal.unja.ac.id/index.php/gentala email : penyunting.jurnal.g-pgsd国unja.ac.id

Dari kegiatan pembelajaran yang telah dilaksanakan dapat diketahui kemampuan dalam menulis cerita pendek berdasarkan kesesuaian isi dengan gambar, ejaan dan tanda baca, struktur kalimat, dan keruntutan cerita siswa kelas VI dalam sangatlah rendah. Sehingga dapat disimpulkan bahwa siswa kelas VI mengalami permasalahan yaitu: siswa belum mampu menulis cerita pendek dengan memperhatikan kesesuaian isi dengan gambar, ejaan dan tanda baca, dan keruntutan cerita.

Dari analisis masalah yang dilakukan maka diperoleh penyebab masalah siswa belum mampu menulis cerita, yaitu: (1) Upaya guru untuk membangkitkan semangat siswa dalam menuangkan ide dalam menulis cerita pendek masih kurang, (2) Kurangnya pengayaan perbendaharaan kata bahasa Indonesia yang dimiliki siswa, (3) Kurangnya peran siswa dalam proses pembelajaran menulis cerita pendek, sehinggga daya kemenarikan terhadap sajian pembelajaran menulis cerita pendek ini menjadi rendah, (4) siswa tidak bersungguh-sungguh mengerjakan tugas yang diberikan, (5) rendahnya pemanfaatan media pembelajaran sebagai penunjang kegiatan pembelajaran.

Dari faktor penyebab kesulitan siswa dalam menulis cerita pendek diperlukan suatu tindakan untuk mengatasi permasalahan yang terjadi selama berlangsungnya pembelajaran menulis cerita pendek di kelas VI. Upaya yang dilakukan adalah dengan menerapkan model pembelajaran kooperatif tipe roundtable berbantuan media gambar seri.

Menurut Aruan (2015) "pembelajaran kooperatif merupakan pembelajaran dimana siswa memiliki kesempatan untuk berinteraksi dengan aktif dalam kelompok belajar karena tujuan kelompok adalah untuk menyelesaikan tugas-tugas dan melaporkannya dalam diskusi kelas". hal ini sejalan dengan pengertian yang dikemukakan oleh Tambak (2017) bahwa "pembelajaran kooperatif menekankan pada sikap atau perilaku bersama dalam bekerja atau membantu diantara sesama, struktur bekerja sama yang teratur dalam kelompok yang tediri atas dua orang atau lebih".

Budayani (2015) mengatakan "Model kooperatif tipe Roundtable merupakan metode pembelajaran yang menerapkan pembelajaran dengan menunjuk tiap-tiap anggota kelompok untuk berpartisipasi secara bergiliran dalam kelompoknya dengan membentuk meja bundar atau duduk melingkar". Sejalan dengan yang disampaikan Huda (2016) "model kooperatif tipe roundtable adalah kegiatan pembelajaran yang menuntut setiap siswa berpartisipasi aktif menunjukkan keterampilan yang dimiliki melalui sumbang ide dalam kelompok dengan jalan duduk melingkar atau membentuk meja bundar". 


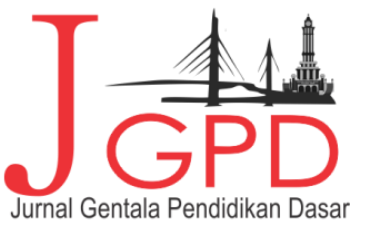

JURNAL GENTALA PENDIDIKAN DASAR Vol.5 No. I Juni 2020, Halaman 78-90

P-ISSN : 2614-7092, E-ISSN : 2621-96II

Terbit Online Pada Laman Web : hittp://online-journal.unja.ac.id/index.php/gentala email : penyunting.jurnal.g-pgsd国unja.ac.id

Berdasarkan pendapat tersebut dapat diartikan bahwa model kooperatif tipe Roundtable merupakan suatu model pembelajaran dimana siswa belajar bersama di dalam suatu kelompok yang mana setiap siswa dalam kelompok tersebut berperan aktif menyumbang ide atau gagasan secara bergiliran dengan duduk melingkar atau meja bundar.

Dalam implementasinya secara teknis Aruan (2015) mengemukakan langkah-langkah dalam model pembelajaran kooperatif tipe roundtable sebagai berikut:

(1) Siswa dibagi ke dalam beberapa kelompok, masing-masing kelompok terdiri dari 4 sampai 5 orang secara heterogen. Masing-masing siswa duduk sesuai dengan kelompoknya dengan posisi membentuk lingkaran mengelilingi meja; (2) Siswa berdiskusi dalam kelompoknya mengenai suatu tema dan menyamakan persepsi. Masing-masing anggota kelompok menyumbangkan idenya terkait dengan tema tersebut secara bergiliran pada kertas yang telah dibagikan; (3) Siswa pertama menyumbangkan idenya dan menuliskan namanya, kemudian dilanjutkan oleh siswa kedua dan seterusnya hingga siswa terakhir dalam kelompok. Penyusunan ide-ide tersebut dilakukan secara kolaborasi; (4) Ide-ide yang sudah terkumpul digunakan sebagai bahan setiap anggota kelompok untuk menyusun karangan secara individu. Karangan masing-masing anggota kelompok yang telah tercipta ditukarkan dan didiskusikan dalam kelompok untuk dilakukan pengeditan; (5) Masing-masing kelompok diminta memilih dan menentukan satu karangan unggulan dalam kelompoknya untuk ditampilakan di depan kelas.

Kelebihan model pembelajaran kooperatif tipe roundtable menurut Barkley (dalam Noviasari, 2017) ialah sebagai berikut: “(1) membantu memfokuskan perhatian kepada siswa, (2) adanya partisipasi dan interaksi antar siswa, (3) mendorong semua siswa untuk mencurahkan gagasan-gagasan dan pendapat, (4) siswa belajar kritis dan kreatif".

Kelemahan model pembelajaran kooperatif tipe roundtable menurut Barkley (dalam Noviasari, 2017) ialah sebagai berikut: “(1) banyak menghabiskan waktu, (2) sejumlah siswa mungkin bingung karena belum terbiasa dengan perlakuan seperti ini”.

Aqib (2013) mengatakan "Media pembelajaran merupakan segala sesuatu yang dapat digunakan untuk menyalurkan pesan dan merangsang terjadinya proses belajar pada siswa". Sedangkan menurut Audina dan Idham (2018) media pembelajaran adalah "segala sesuatu yang diperlukan dalam kegiatan belajar mengajar untuk menjelaskan hal yang bersifat abstrak menjadi lebih konkret dan dapat menarik minat siswa dalam memahami materi yang sudah disampaikan oleh guru melalui bahasa verbal".

Menurut Imamsyah, Suhartono, dan Warsiti (2012) "gambar seri merupakan media visual yang bersifat sederhana, mudah dilihat, tidak terlalu mahal, mudah dipahami, dan memudahkan dalam kegiatan menulis". Sedangkan menurut Audina dan Idham (2018) 


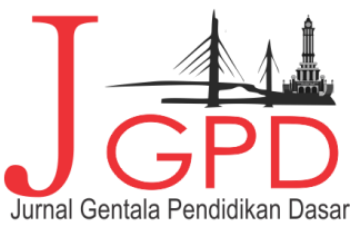

JURNAL GENTALA PENDIDKAN DASAR Vol.5 No. I Juni 2020, Halaman78-90 P-ISSN : 2614-7092, E-ISSN : 2621-96II Terbit Online Pada Laman Web : hittp://online-journal.unja.ac.id/index.php/gentala email : penyunting.jurnal.g-pgsd国unja.ac.id

"gambar seri adalah media gambar yang terdiri dari beberapa gambar yang disusun saling berkaitan antara gambar yang satu dengan gambar lain sehingga membentuk satu cerita dalam bentuk gambar".

Dapat disimpulkan bahwa media gambar seri adalah media visual sederhana yang terdiri atas beberapa gambar yang disusun dan saling berhubungan antara setiap gambar sehingga terbentuk suatu cerita dalam bentuk gambar untuk memudahkan dalam kegiatan menulis.

Gambar seri mampu merangsang pikiran siswa untuk mengembangkan penalaran yang dimiliki ke dalam sebuah tulisan dengan berbantuan gambar. Siswa diberi kesempatan untuk membuat karangan atau melukiskan pikirannya menjadi sebuah cerita dan siswa tidak merasa haknya digantikan oleh guru dalam menuangkan buah pikirannya. Dengan demikian gambar seri mampu melatih siswa meningkatkan keterampilan menulis narasi dari gambar menjadi kata, kata dikembangkan menjadi kalimat, kalimat menjadi paragraf sehingga terbentuk sebuah tulisan yang utuh. (Muliantara, Tastra, dan Arini, 2014).

Beberapa kelebihan yang dimiliki oleh media gambar menurut Nutabonis (2016) adalah sebagai berikut: "(1) Media gambar seri adalah media yang sangat menyenangkan karena siswa lebih aktif dalam mengikuti pelajaran, (2) Materi yang dipelajari melalui media gambar lebih mudah diserap oleh siswa, (3) Siswa lebih mudah untuk menangkap isi dan maksud gambar seri”.

Menurut Imamsyah, Suhartono, dan Warsiti (2012) menulis sebagai "kegiatan menuangkan ide, gagasan, atau pikiran menjadi sebuah karya, yang lebih jauh manfaatnya adalah agar dapat mengkomunikasikan ide, gagasan, atau pikiran kita dengan orang lain”. Sedangkan menurut Aruan (2015) "menulis adalah kegiatan yang melibatkan pikiran dan perasaan, kemudian diungkapkan ke dalam bentuk-bentuk tulisan dengan menggunakan bahasa yang komunikatif, sehingga pembaca dapat mengerti dan memahami apa yang disampaikan oleh penulis".

Mastini, Suwandi, dan Sumarwati (2016) mengemukakan bahwa "cerita pendek adalah karya sastra berbentuk prosa yang isi ceritanya mengisahkan permasalahan kehidupan suatu tokoh yang diceritakan secara ringkas dan berfokus pada suatu tokoh, serta dimediakan secara lisan ataupun tulisan".

Menulis cerita pendek di SD Kelas VI indikatornya berupa menulis cerita fiksi dalam bentuk cerita pendek kedalam beberapa kalimat dengan memperhatikan ejaan dan tanda baca. 


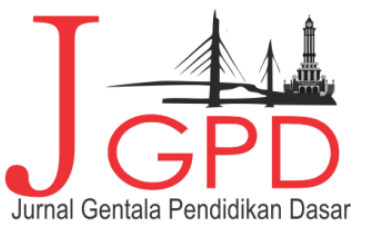

JURNAL GENTALA PENDIDKAN DASAR Vol.5 No. I Juni 2020, Halaman 78-90 P-ISSN : 2614-7092, E-ISSN : 2621-96II Terbit Online Pada Laman Web : hittp://online-journal.unja.ac.id/index.php/gentala email : penyunting.jurnal.g-pgsd国unja.ac.id

Cerita pendek yang akan ditulis siswa terdiri dari 10-40 kalimat dan sesuai dengan kriteria penilaian dalam menulis cerita pendek menurut Muliantara, Tastra, dan Arini (2014) yaitu kesesuaian isi dengan gambar, ejaan dan tanda baca, dan keruntutan cerita.

\section{METODE PENELITIAN}

Penelitian yang akan dilaksanakan merupakan Penelitian Tindakan Kelas (PTK). Yulmaliza (2018) mengatakan PTK adalah suatu bentuk kajian yang bersifat sistematis reflektif oleh pelaku tindakan untuk memperbaiki kondisi pembelajaran yang dilakukan dengan tujuan utama untuk memperbaiki/meningkatkan praktek pembelajaran secara berkesinambungan serta tujuan penyetaraan adalah menumbuhkan budaya meneliti dikalangan guru. Model yang dipilih adalah model spiral menurut Kemmis dan Mc Taggart. Hendarini (2016) menyatakan model Kemmis mengembangkan model yang sederhana yang pada tiap siklusnya terdiri dari empat tahap, yaitu perencanaan, pelaksanaan, pengamatan, dan refleksi.

Penelitian ini akan dilaksanakan di SDN No. 93/I Lopak Aur yang beralamat di RT 06 Kecamatan Pemayung Kabupaten Batanghari Propinsi Jambi. Sekolah ini terletak kurang lebih $10 \mathrm{~km}$ dari pusat kota kecamatan. Subjek dalam penelitian adalah siswa kelas VI.A pada tahun ajaran 2019-2020 yang jumlah siswanya 20 orang; 11 orang siswa perempuan dan 9 orang siswa laki-laki. Penelitian Tindakan Kelas ini terdiri dari empat tahapan yaitu perencanaan, pelaksanaan, observasi, dan refleksi.

Tahap perencanaan penelitian ini akan dilaksanakan oleh peneliti yang juga sebagai guru kelas VI.A di SDN No. 93/I Lopak Aur dengan persiapan-persiapan yang terdiri dari: (1) Menyusun materi pembelajaran yaitu menulis cerita pendek yang dituangkan dalam RPP kurikulum 2013, (2) Menyusun skenario pembelajaran yang sesuai dengan model pembelajaran kooperatif tipe roundtable, (3) Menyiapkan media/alat peraga yang berhubungan dengan materi pembelajaran menulis cerita pendek yaitu gambar seri, (4) Membuat LKS menulis cerita pendek untuk mengetahui peningkatan hasil belajar siswa setelah model pembelajaran kooperatif tipe roundtable berbantuan media gambar seri di terapkan, (5) Menyiapkan lembar observasi kinerja guru dan aktifitas siswa untuk mengamati proses pembelajaran dengan menerapkan model pembelajaran kooperatif tipe roundtable berbantuan media gambar seri untuk meningkatkan kemampuan menulis cerita pendek. 


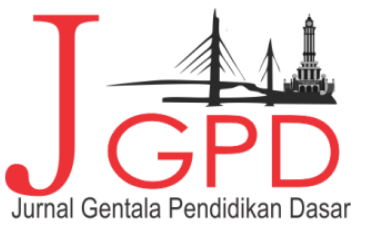

JURNAL GENTALA PENDIDKAN DASAR Vol.5 No. I Juni 2020, Halaman 78-90 P-ISSN : 2614-7092, E-ISSN : 2621-96II Terbit Online Pada Laman Web : hittp://online-journal.unja.ac.id/index.php/gentala email : penyunting.jurnal.g-pgsd国unja.ac.id

Pada tahap pelaksanaan tindakan diimplementasi atau diterapkan isi rancangan, yaitu penerapan tindakan di kelas. Pada tahap ini, dilaksanakan kegiatan pembelajaran sesuai dengan RPP yang disusun pada tahap perencanaan. RPP yang dilaksanakan menerapkan model pembelajaran kooperatif tipe roundtable dan media gambar seri pada keterampilan menulis cerita pendek. pelaksanaannya sesuai dengan jadwal pelajaran tatap muka yang telah disusun sebelumnya.

Tahap observasi peneliti menggunakan audio visual berupa merekam semua kegiatan atau aktivitas guru dan siswa di kelas selama berlangsungnya pembelajaran menulis cerita pendek dengan penerapan model pembelajaran kooperatif tipe roundtable berbantuan media gambar seri.

Langkah yang diambil dalam melakukan observasi adalah: (1) Observasi bagaimana kinerja guru dalam pelaksanaan pembelajaran menulis cerita pendek dengan penerapan model pembelajaran kooperatif tipe roundtable berbantuan media gambar seri, (2) Observasi bagaimana aktifitas siswa terhadap pembelajaran menulis cerita pendek yang meliputi: (1) keaktifan, (2) kerja sama, (3) tanggung jawab dengan menggunakan instrument lembar observasi. Selain melakukan kegiatan observasi juga dilakukan kegiatan evaluasi untuk mengevaluasi proses belajar siswa yang dilaksanakan pada setiap akhir siklus yang dilakukan oleh peneliti. Aspek yang dievaluasi meliputi aspek: (1) kesesuaian isi dengan gambar, (2) ejaan dan tanda baca, (3) struktur kalimat, (4) keruntutan cerita.

Refleksi merupakan bagian yang sangat penting untuk memahami dan memberikan makna terhadap proses dan hasil pembelajaran yang terjadi yang dilakukan dengan cara sebagai berikut: (1) Pengecekan kelengkapan data yang terjaring selama proses tindakan berlangsung, (2) Analisis semua informasi yang diperoleh dari pelaksanaan tindakan, (3) Melakukan evaluasi terhadap keberhasilan dan pencapaian tujuan tindakan, (4) penyusunan rencana tindakan selanjutnya yang dirumuskan dalam skenario pembelajaran dengan berdasarkan pada analisis data yang terkumpul untuk memperbaiki proses pembelajaran yang telah dilakukan.

Untuk mengetahui keberhasilan dalam proses pembelajaran dan hasil penyajian materi diambil data yang diolah yaitu data kualitatif dan data kuantitatif.

1. Data observasi

Untuk menganalisis data hasil observasi aktifitas siswa digunakan rumus Mahanurani, Setiawan, dan Oktavianingtyas (2016) sebagai berikut: 


$$
\mathrm{P}_{\mathrm{I}}=
$$

$m$ $\mathrm{X} 100 \%$

Keterangan :

$\Sigma$ Skor maksimal

$\mathrm{P}_{\mathrm{I}}=$ Persentase keaktifan siswa

$\mathrm{m}=$ Jumlah skor yang diperoleh siswa

Untuk menganalisis data observasi aktifitas guru digunakan rumus Mahanurani, Setiawan, dan Oktavianingtyas (2016) sebagai berikut :
$\mathrm{P} 2=$ $\mathrm{m}$ $\mathrm{X} 100 \%$

Keterangan :

$\mathrm{P} 2=$ Persentase keaktifan guru

$\mathrm{m}=$ Jumlah skor yang diperoleh guru

\section{Data evaluasi}

Untuk menilai hasil tes menulis ceita pendek dilakukan penjumlahan nilai yang diperoleh peserta didik yang selanjutnya dibagi dengan jumlah peserta didik yang ada di kelas sehingga diperoleh nilai rata-rata. Untuk mencari nilai rata-rata digunakan rumus Yulmaliza (2018:3) sebagai berikut:$$
\mathrm{x}=\frac{\sum \mathrm{X}}{\sum \mathrm{N}}
$$

Keterangan:

$\mathrm{x}=$ nilai rata-rata

$\sum X=$ jumlah semua nilai siswa

$\sum \mathrm{N}=$ jumlah siswa
}

Indikator yang digunakan untuk mengetahui keberhasilan tindakan adalah dengan hasil kemampuan menulis cerita pendek dengan format kesesuaian isi dengan gambar, ejaan dan tanda baca, struktur kalimat, dan keruntutan cerita. Untuk mengetahui ketuntasan belajar secara klasikal, jika siswa yang telah memperoleh nilai lebih atau sama dengan 7 minimal 80\% dari keseluruhan siswa, digunakan rumus Yulmaliza (2018:4) sebagai berikut:

$$
\mathrm{p}=\frac{\sum \text { siswa yang tuntas belajar }}{\sum \text { siswa }} \quad \mathrm{X} 100 \%
$$

Tabel Klasifikasi Ketuntasan Klasikal

\begin{tabular}{|c|c|}
\hline Persentase & Kategori \\
\hline $80 \%-100 \%$ & Sangat baik \\
\hline $70 \%-79 \%$ & Baik \\
\hline $60 \%-69 \%$ & Cukup \\
\hline$<59 \%$ & Kurang \\
\hline
\end{tabular}

(Djamarah dalam Fahlevi, 2019) 
Dengan diterapkannya model pembelajaran kooperatif tipe rountable berbantuan media gambar seri maka diharapkan akan semakin meningkatkan kemampuan menulis cerita pendek siswa.

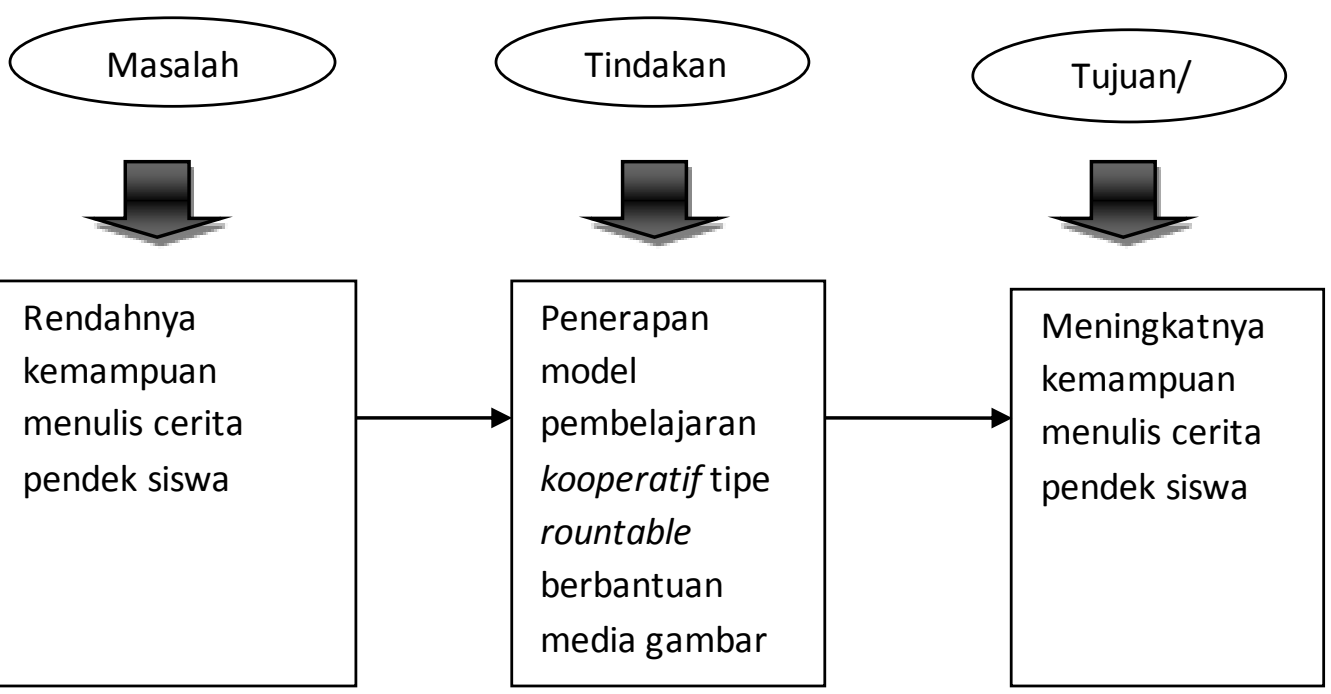

\section{Gambar. Bagan Kerangka Konseptual}

\section{HASIL PENELITIAN DAN PEMBAHASAN}

Penelitian Tindakan Kelas ini dilakukan dalam dua siklus dan tiap siklus terdiri dari dua pertemuan. Pada siklus I dari hasil evaluasi kemampuan siswa dalam menulis cerita pendek dan observasi kinerja guru dan keaktifan siswa yang dilakukan mengalami peningkatan, namun untuk ketuntasan belum dapat dinyatakan tuntas karena jumlah siswa yang tuntas belum mencapai 80 persen.

Pada siklus I untuk hasil observasi siswa dari ketiga aspek maka 8 orang siswa (40\%) memperoleh predikat baik (B), 8 orang siswa (40\%) memperoleh predikat cukup (C), 4 orang siswa (20\%) memperoleh predikat kurang (K). Sementara untuk hasil observasi kinerja guru dari aspek yang diamati 3 aspek memperoleh hasil baik (27\%), kemudian 7 aspek memperoleh hasil cukup (63\%) dan 1 aspek memperoleh hasil kurang (9\%). Ini artinya aktivitas guru dalam mengajar belum dapat dikatakan baik. Sementara untuk nilai evaluasi siswa sebanyak 12 orang siswa $(60 \%)$ telah tuntas dan 8 orang siswa (40\%) belum tuntas dengan rata-rata kelas $68 \%$. 
Tabel 1 Hasil Observasi Aktifitas Siswa Siklus I

\begin{tabular}{|l|l|l|l|}
\hline No & Aspek yang dinilai & Jumlah siswa & \% ketuntasan \\
\hline 1 & Keaktifan & & \\
& 3 & 8 & $40 \%$ \\
& 2 & 9 & $45 \%$ \\
& 1 & $75 \%$ \\
\hline 2 & Kerja sama & 10 & \\
& 3 & 8 & $50 \%$ \\
& 2 & 6 & $40 \%$ \\
& 1 & & $30 \%$ \\
\hline 3 & Tanggung jawab & 9 & \\
& 3 & 8 & $45 \%$ \\
& 2 & 7 & $35 \%$ \\
& 1 & & \\
\hline
\end{tabular}

Tabel 2 Hasil Observasi Kinerja Guru Siklus I

\begin{tabular}{|c|l|c|}
\hline No & Aspek yang diamati & Hasil pengamatan \\
\hline 1 & Guru meminta ketua kelas memimpin doa & $\mathrm{C}$ \\
2 & Guru membimbing menyanyikan lagu Indonesia Raya & $\mathrm{B}$ \\
3 & Guru memberikan appersepsi & $\mathrm{K}$ \\
4 & Guru menyampaikan kompetensi & $\mathrm{C}$ \\
5 & Guru memberikan motivasi kepada siswa & $\mathrm{B}$ \\
6 & Guru membentuk kelompok siswa & $\mathrm{B}$ \\
7 & Guru memberikan tugas kepada kelompok & $\mathrm{C}$ \\
8 & Guru meminta siswa melaporkan hasil diskusi & $\mathrm{C}$ \\
9 & Guru bertanya jawab bersama siswa & $\mathrm{C}$ \\
10 & Guru memberikan kesimpulan & $\mathrm{C}$ \\
11 & Guru memberikan umpan balik dan tindak lanjut & $\mathrm{C}$ \\
\hline
\end{tabular}

Tabel 3 Hasil Evaluasi Kemampuan Mennulis Cerita Pendek Siklus I

\begin{tabular}{|l|l|l|l|}
\hline No & Aspek yang dinilai & Jumlah siswa & $\begin{array}{l}\text { \% } \\
\text { ketuntasan }\end{array}$ \\
\hline 1 & Kesesuaian isi dengan gambar & & \\
& 3 & 1 & $5 \%$ \\
& 2 & 17 & $85 \%$ \\
& 1 & 2 & $10 \%$ \\
\hline 2 & Ejaan dan tanda baca & & \\
& 3 & 5 & $25 \%$ \\
& 2 & 11 & $55 \%$ \\
& 1 & 4 & $20 \%$ \\
\hline 3 & Keruntutan cerita & 6 & \\
& 3 & 9 & $30 \%$ \\
& 2 & 5 & $45 \%$ \\
& 1 & & $25 \%$ \\
\hline
\end{tabular}


Pada siklus II untuk hasil observasi siswa dari ketiga aspek maka 16 orang siswa (80\%) memperoleh predikat baik (B), 4 orang siswa (20\%) memperoleh predikat cukup (C). (100\%). Untuk nilai evaluasi siswa maka siswa yang tuntas sebanyak 18 orang siswa (90\%) dan 2 orang siswa (10\%) dinyatakan tidak tuntas dengan rata-rata kelas 90,45\%.

Dari data pada siklus II dapat disimpulkan bahwa proses pembelajaran menulis cerita pendek dengan model pembelajaran kooperatif tipe roundtable berbantuan media gambar seri telah mencapai hasil yang memuaskan. Dengan kata lain, apabila dihubungkan dengan kriteria keberhasilan telah memenuhi kriteria yang telah ditetapkan. Maka penelitian ini dihentikan cukup pada siklus II.

Tabel 4 Hasil Observasi Keaktifan Siswa Siklus II

\begin{tabular}{|l|l|l|l|}
\hline No & Aspek yang dinilai & Jumlah siswa & \% ketuntasan \\
\hline 1 & Keaktifan & & \\
& 3 & 15 & $75 \%$ \\
& 2 & 4 & $20 \%$ \\
& 1 & 1 & $5 \%$ \\
\hline 2 & Kerja sama & & \\
& 3 & 16 & $80 \%$ \\
& 2 & 4 & $20 \%$ \\
& 1 & 0 & $0 \%$ \\
\hline 3 & Tanggung jawab & 12 & \\
& 3 & 7 & $60 \%$ \\
& 2 & 1 & $35 \%$ \\
& 1 & \multicolumn{2}{|}{} \\
\hline
\end{tabular}

Tabel 5 Hasil Observasi Kinerja Guru Siklus II

\begin{tabular}{|c|l|c|}
\hline No & Aspek yang diamati & Hasil pengamatan \\
\hline 1 & Guru meminta ketua kelas memimpin doa & B \\
2 & Guru membimbing menyanyikan lagu Indonesia Raya & B \\
3 & Guru memberikan appersepsi & B \\
4 & Guru menyampaikan kompetensi & B \\
5 & Guru memberikan motivasi kepada siswa & B \\
6 & Guru membentuk kelompok siswa & B \\
7 & Guru memberikan tugas kepada kelompok & B \\
8 & Guru meminta siswa melaporkan hasil diskusi & B \\
9 & Guru bertanya jawab bersama siswa & B \\
10 & Guru memberikan kesimpulan & B \\
11 & Guru memberikan umpan balik dan tindak lanjut & B \\
\hline
\end{tabular}




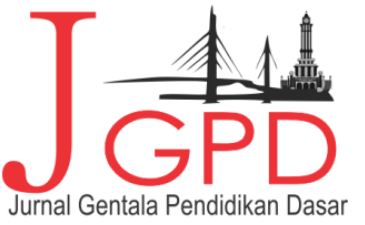

JURNAL GENTALA PENDIDKAN DASAR Vol.5 No. I Juni 2020, Halaman 78-90 P-ISSN : 2614-7092, E-ISSN : 2621-96II

Terbit Qnline Pada Laman Web : hittp://online-journal.unja.ac.id/index.php/gentala email : penyunting.jurnal.g-pgsd国unja.ac.id

Tabel 6 Hasil Evaluasi Kemampuan Menulis Cerita Pendek Siklus II

\begin{tabular}{|l|l|l|l|}
\hline No & Aspek yang dinilai & Jumlah siswa & \% ketuntasan \\
\hline 1 & Ketepatan pilihan kata & & \\
& 3 & 17 & $85 \%$ \\
& 2 & 3 & $15 \%$ \\
& 1 & 0 & $0 \%$ \\
\hline 2 & Kepaduan kalimat & & \\
& 3 & 15 & $75 \%$ \\
& 2 & 5 & $25 \%$ \\
& 1 & 0 & $0 \%$ \\
\hline 3 & Kepaduan cerita & & \\
& 3 & 16 & $80 \%$ \\
& 2 & 2 & $10 \%$ \\
& 1 & 0 & $0 \%$ \\
\hline
\end{tabular}

\section{PEMBAHASAN}

Berdasarkan analisis penelitian, diperoleh bahwa penerapan model pembelajaran kooperatif tipe roundtable berbantuan media gambar seri menjadikan siswa dapat bekerja sama dan berdiskusi dengan teman dalam kelompoknya untuk menyelesaikan cerita pendek, siswa berani menyampaikan hasil diskusinya, dan siswa mempunyai rasa tanggung jawab terhadap tugas yang diberikan.

Seiring dengan itu, dalam proses pembelajaran menerapkan model pembelajaran kooperatif tipe roundtable berbantuan media gambar seri dapat membangkitkan minat belajar siswa, menjadikan suasana belajar bergairah dan menyenangkan, membuat perubahan yang signifikan terhadap tingkah laku siswa, memperluas wawasan dan pengalaman siswa, terbentuk kerja sama dan sikap tolong menolong siswa.

Dari hasil penelitian tindakan kelas ini dapat disimpulkan bahwa penerapan model pembelajaran kooperatif tipe roundtable berbantuan media gambar seri dapat meningkatkan kemampuan menulis cerita pendek siswa kelas VI A SDN No. 93/I Lopak Aur. Keberhasilan ini dapat ditunjukkan oleh indikator sebagai berikut :

- Hasil observasi aktivitas siswa pada siklus II 16 orang memperoleh predikat baik.

- Hasil evaluasi siswa pada siklus II mencapai rata-rata 90,45 dan siswa yang tuntas mencapai $90 \%$.

Untuk melihat lebih jelas keterhubungan hasil penelitian pada masing-masing siklus dengan kriteria keberhasilan yang ditetapkan, berikut disajikan rekapitulasi hasil observasi dan evaluasi kemampuan menulis cerita pendek siswa kela VI A SDN No. 93/I Lopak Aur pada siklus I dan siklus II. 


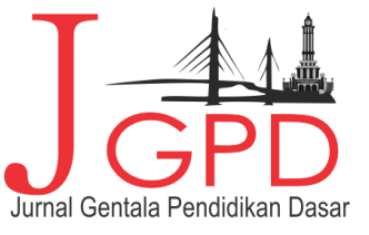

JURNAL GENTALA PENDIDIKAN DASAR Vol.5 No. I Juni 2020, Halaman 78-90

P-ISSN : 2614-7092, E-ISSN : 2621-96il

Terbit Online Pada Laman W eb : http://unline-juurnal.unja.ac.id/index.php/gentala email : peny unting.jurnal.g-pgsd国unja.ac.id

Tabel Rekapitulasi Keaktifan Siswa SDN No. 93/I Lopak Aur

\begin{tabular}{|c|c|c|c|}
\hline No & Predikat & Siklus I & Siklus II \\
\hline 1 & Baik & 8 orang & 16 orang \\
\hline 2 & Cukup & 8 orang & 4 orang \\
\hline 3 & Kurang & 4 orang & - \\
\hline
\end{tabular}

Tabel Rekapitulasi Kemampuan Menulis Cerita Pendek Siswa SDN No. 93/I Lopak Aur

\begin{tabular}{|c|c|c|c|}
\hline No & Predikat & Siklus I & Siklus II \\
\hline 1 & Tuntas & 12 orang & 18 orang \\
\hline 2 & Tidak & 8 orang & 2 orang \\
& Tuntas & & \\
\hline & Rata-rata & 68 & 90,45 \\
\hline
\end{tabular}

\section{KESIMPULAN DAN IMPLIKASI}

Berdasarkan penelitian tindakan kelas yang telah dilakukan, yaitu menggunakan model pembelajaran kooperatif tipe roundtable berbantuan media gambar seri maka dapat disimpulkan sebagai berikut:

1. Penerapan model pembelajaran kooperatif tipe roundtable berbantuan media gambar seri dengan cara siswa belajar dan berdiskusi bersama dalam kelompok dapat meningkatkan kemampuan menulis cerita pendek pada siswa kelas VI A SDN No. 93/I Lopak Aur, hal ini terbukti dari hasil observasi dan evaluasi pada tiap tahapan siklus. Hasil observasi aktivitas siswa pada siklus I $40 \%$ atau 8 orang siswa memperoleh predikat B, pada siklus II, $80 \%$ atau 16 orang siswa memperoleh predikat B. dari hasil evaluasi siklus I siswa yang tuntas $60 \%$ atau 12 orang siswa, pada siklus II siswa yang tuntas $90 \%$ atau 18 orang siswa.

2. Pembelajaran menulis cerita pendek dengan penerapan model pembelajaran kooperatif tipe roundtable berbantuan media gambar seri menjadikan siswa mampu membangun sendiri pengetahuan meraka, menemukan suasana dan ide-ide baru yang menyenangkan dalam pembelajaran, siswa dapat bekerja sama dengan teman dan saling membantu dalam kegiatan pembelajaran.

\section{DAFTAR PUSTAKA}

Aqib, Z. (2013). Model-Model, Media, dan Strategi Pembelajaran Kontekstual. Bandung: Yrama Widya.

Aruan, L. (2015). Model Pembelajaran Kooperatif Roundtable Terhadap Kemampuan Menulis Mahasiswa Program Studi Pendidikan Bahasa Jerman. 


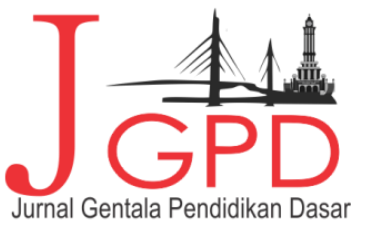

JURNAL GENTALA PENDIDIKAN DASAR Vol.5 No. I Juni 2020, Halaman 78-90 P-ISSN : 2614-7092, E-ISSN : 2621-96II

Terbit Online Pada Laman Web : hittp://online-journal.unja.ac.id/index.php/gentala email : penyunting.jurnal.g-pgsd回unja.ac.id

Audina,M \& Idham, M. (2018). Penggunaan Media Gambar Seri pada Pembelajaran Menulis Teks Negoisasi di Kelas X SMAN Unggul Tunas Bangsa Aceh Barat Daya, Jurnal Bahasa dan Sastra 12(1)

Budayani, I. (2015). Penerapan Metode Pembelajaran Roundtable Untuk Meningkatkan Hasil Belajar Bahasa Inggris Pada Siswa Kelas VIII-5 SMP Negeri 30 Pekanbaru Tahun Ajaran 2015-2016. Jurnal Ilmu Pendidikan Sosial, Sains, dan Humaniora 1(1). Fahlevi, M.R. (2019). Peningkatan Kerja Sama dan Hasil Belajar Siswa Kelas VI pada Pembelajaran IPS Melalui Model Make A Match di SDN 117/X Muara Sabak Timur.

Hendarini, A. D. (2016).Peningkatan Keterampilan Menulis Cerita Pendek dengan Menggunakan Model Pembelajaran Berbasis Pengalaman pada Sisa Kelas X SMA.

Huda, T. P. (2016). Penerapan Model Kooperatif Tipe Roundtable dalam Pembelajaran Menulis Teks Eksposisi Pada Siswa Kelas X SMA. Riksa Bahasa 2(2).

Imamsyah, Suhartono, Warsiti. (2013). Penggunaan Media Gambar Seri dalam Peningkatan Keterampilan Menulis Karangan bagi Siswa Kelas V SD

Mahanurani, I., Setiawan, T.B., Oktavianingtyas, E. (2016). Penerapan Model Pembelajaran Kooperatif Tipe Roundtable Untuk Meningkatkan Aktivitas dan Hasil Belajar Siswa Pada Pokok Bahasan Segitiga Kelas VII SMP Negeri 2 Pasirian Tahun Ajaran 2015/2016.Jurnal Kadikma 7(1).

Mastini, Suwandi, S., Sumarwati. (2016). Peningkatan Keterampilan Menulis Cerpen Melalui Metode Pembelajaran Berbasis Pengalaman dan Media Audio Visual Pada Sekolah Menengah Pertama. Jurnal S2 Pendidikan Bahasa Indonesia 1(1).

Muliantara, I.K., Tastra, I.D.K., Arini, N.W. (2014). Penerapan Media Gambar Seri Untuk Meningkatkan Keterampilan Menulis Narasi Pada Siswa Kelas III Sekolah Dasar Negeri 5 Sudaji Kecamatan Sawan. Jurnal Mimbar PGSD Universitas Pendidikan Ganesha 2(1).

Noviasari. F. (2017). Penerapan Model Kooperatif Teknik Roundtable untuk Meningkatkan Motivasi Belajar Sejarah Siswa Kelas XI IPS SMA Negeri 1 Punggur Tahun Ajaran 2016/2017.

Nutabonis, S. (2017). Peningkatan Keterampilan Menulis Karangan Narasi Melalui Penggunaan Media Gambar Seri. Jurnal Pendidikan Guru Sekolah Dasar 7(6).

Tambak, S. (2017). Metode Cooperative Learning dalam Pembelajaran Pendidikan Agama Islam. Jurnal Al-hikmah 14(1).

Yulmaliza. (2018). Penerapan Model Pembelajaran Kooperatif Tipe Roundtable dapat Meningkatkan Hasil Belajar pada Pokok Bahasan Aritmatika Sosial di Kelas VII 8 SMP Negeri 10 Pekanbaru. Jurnal Pendidikan dan Keguruan 9(2). 